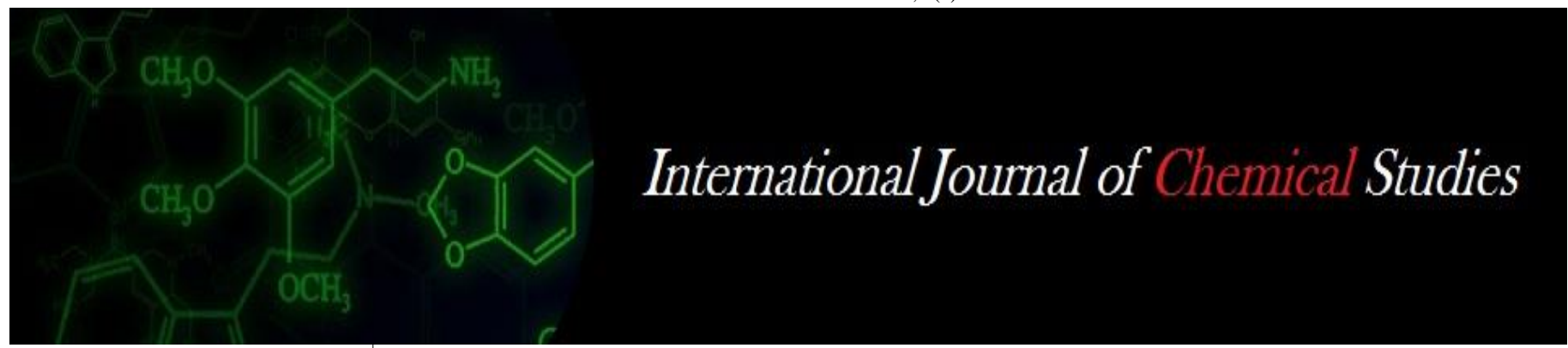

P-ISSN: 2349-8528

E-ISSN: 2321-4902

www.chemijournal.com

IJCS 2020; 8(2): 1567-1574

(C) 2020 IJCS

Received: 15-01-2020

Accepted: 19-02-2020

Reemah Mohammed Abdullah Sallam

Department of Environmental

Engineering, Faculty of

Engineering. Sabratha

University, Libya

Corresponding Author:

Reemah Mohammed Abdullah

Sallam

Department of Environmental

Engineering, Faculty of

Engineering. Sabratha

University, Libya

\section{Landfill emissions and their impact on the environment}

\author{
Reemah Mohammed Abdullah Sallam
}

DOI: https://doi.org/10.22271/chemi.2020.v8.i2x.8985

\begin{abstract}
The waste management of Solid-fluid remains a major challenge that faces sustainable environment and human health. Effluents from disposal facilities and waste treatment generate direct as well as indirect impacts on the welfare of humans and the environment. The direct impacts include the material destruction, damage to health and loss of aesthetic values. Also, the indirect effects develop a long term impact, encompassing ecosystem imbalance and climate change. The challenges and mitigating the waste disposal problem has happened to be greater due to high growth rate of population, economic expansion, industrial growth and urbanization. The purpose of this review paper is to obtain the maximum information from the international and national literature, on Waste management, and landfill procedures adopted in every country, and the drastic impacts landfill and incineration practices generate on the environment and human health.
\end{abstract}

Keywords: landfill, social-economic impacts, environmental impacts, waste management, landfill gas.

\section{Introduction}

A modern landfills created an engineered methodical system to depose waste in specially designed, protected and constructed cells on the surface of the land, in the excavated land surface. Presently, a large amount of waste is recycled, reused, or energetically Valorized giving value, even when, landfills play a vital role in WM strategies. The waste degradation in the landfill produces Gases, Leachate, containing contaminants. The emissions are potential human health threats to affect the environment quality. Landfill gases are mainly $\mathrm{CO}_{2}$, methane, the main greenhouse gases. Landfill places produce $22 \%$ of global emissions, developing anthropogenic methane. Moreover, they contain a huge amount of other unwanted, toxic gases, though at a low concentration. The Leachate is sanitary landfill by-product and possibly migrates to groundwater sources, even joins the surface water by the liner flaws posing serious problems as porous land deposits like aquifers needs extensive rehabilitation time. The landfill construction, location and management develop environmental effects, changing landscape structure, fauna displacement and loss of habitats.

The landfill impact Socioeconomic and public health risks derived from groundwater contamination, surface and Leachate, the litter diffusion into the wider ecological system due to inadequate on recycling -site activities (Alobaid, et al., 2018) ${ }^{[2]}$. Flies, smoke, gases, noise and foul odors like Nuisances normally cited and they are the main reasons people refuse to reside near the landfill regions. The researchers concluded that the landfills generate negative and adverse impacts on housing development values based on the real landfill distance. This review paper emphasizes the socioeconomic and environmental impacts referred to landfills and investigates the modern approaches to evaluate these impacts, many of them release hazardous chemicals and toxic materials into the Earth. Moreover, complement with various suggestions to reduce or curtail the landfill burden on the environment by improving the management re-introducing buried landfill resources to recycle and regenerate. Because, landfills produce distinctive effects on land, nature, air pollution and humans (Chen, 2018) ${ }^{[4]}$. 


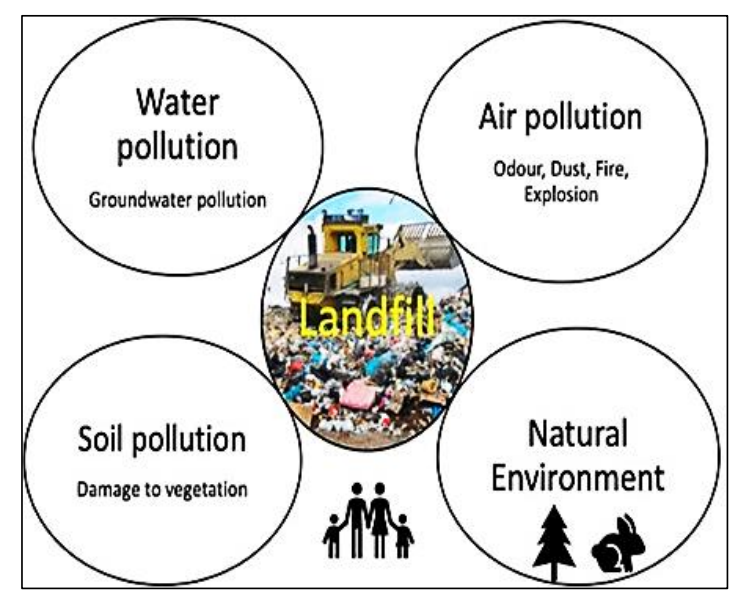

Fig 1: Landfill impact on the environment (Wang, \& Shen, 2000; Ghosh, 2019; Vaverková, 2019) [27, 8, 26].

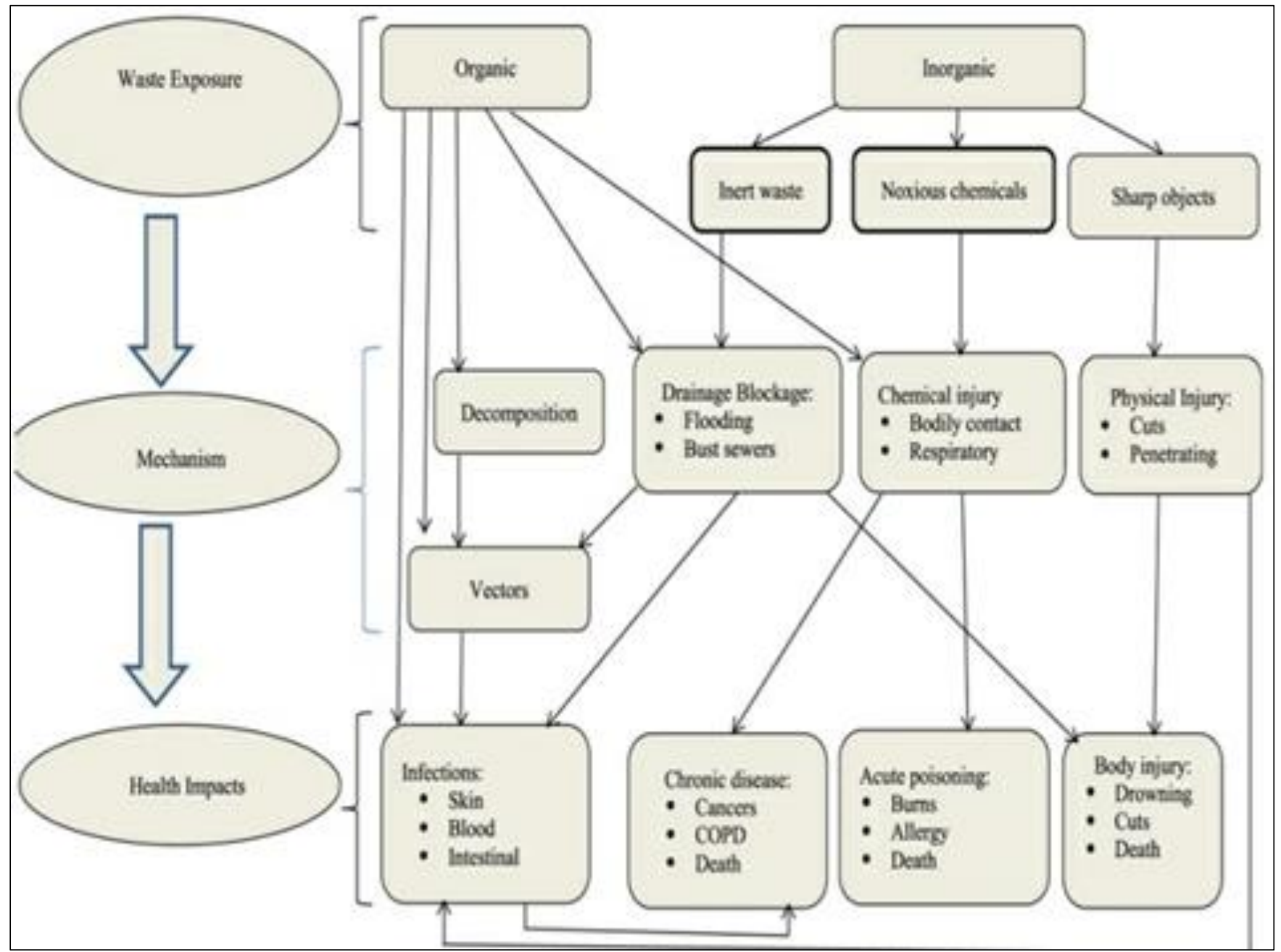

Fig 2: The solid waste management, poor linkages and related adverse health results (Ziraba et al. 2016) ${ }^{[32]}$.

\section{Air and Environmental Pollution}

About $65 \%$ landfill wastes contain organic biodegradable matter from industries, households and business produce an unpleasant smell due to organic waste decay. The decomposed materials release methane gas, as a compelling greenhouse gas, which traps above $65 \%$ additional atmospheric heat related to $\mathrm{CO}_{2}$. In fact, the landfill methane can help produce electricity, generating a by-product $\mathrm{CO}_{2}$, which produce less effect of global warming (Kivimägi, 2011)
[13].

\section{Biodiversity Impacts}

According to the Environment and Forest Ministry, the landfill sites show a loss of nearly 280 species every hectare, replacing new species feeding on refuse, like crows and rats, while further Vegetation changes occur, replaced plants, below earth conditions and so on (Ziyang, et al., 2015) ${ }^{[31]}$. 

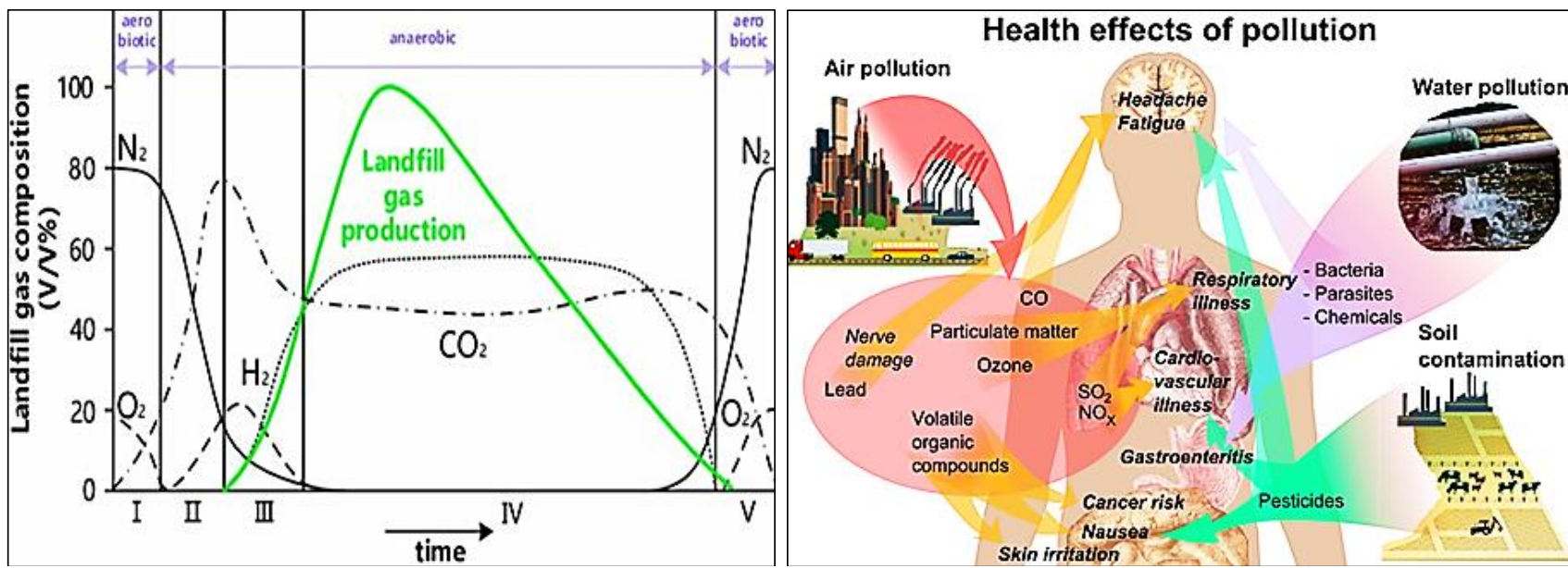

Fig 3: Pollution, Health effects \& Figure: Landfill degradation and gas Composition of every stage (Ziyang, et al., 2015) ${ }^{[31]}$.

\section{Landfill Gas}

From the landfill products, the biological process occurs to produce landfill gas and Biogas called LFG (Shen, et al., 2018) ${ }^{[22]}$. The Biogas is generated due to the decomposition of organic matters carried out from the biological decomposition process (Rada, et al., 2015), mainly because of the production rate of the Biogas and its change in composition around the landfill lifetime. The production of the landfill gas as shown in the below Figure, is mainly happening to the bacterial waste, composite decomposition model and on the long-lasting behavior model of landfill gas production from the previous, rotten waste repositories (Zhao, Zhang, \& e, D. 2017) ${ }^{[30]}$.

\section{Pollution Due to Groundwater}

When the rain comes down on landfill sites, inorganic and organic elements dissolve, concerting into very toxic chemicals and compounds leaching and joining the underground strata and groundwater. They normally contain a large amount of ammonia, high toxic metals, pathogens, and lethal organic elements, resulting in severe groundwater contamination. They generate a high demand of biological oxygen, which promptly Deoxygenate water, to produce Hydrogen sulfide due sulfate-reducing bacterial activities. When such kind of noxious chemicals contact lakes, or rivers, it results in the harmful effects, or even death of aquatic living (Kumar Gupta \& Gayathiri, 2018) ${ }^{[15]}$.
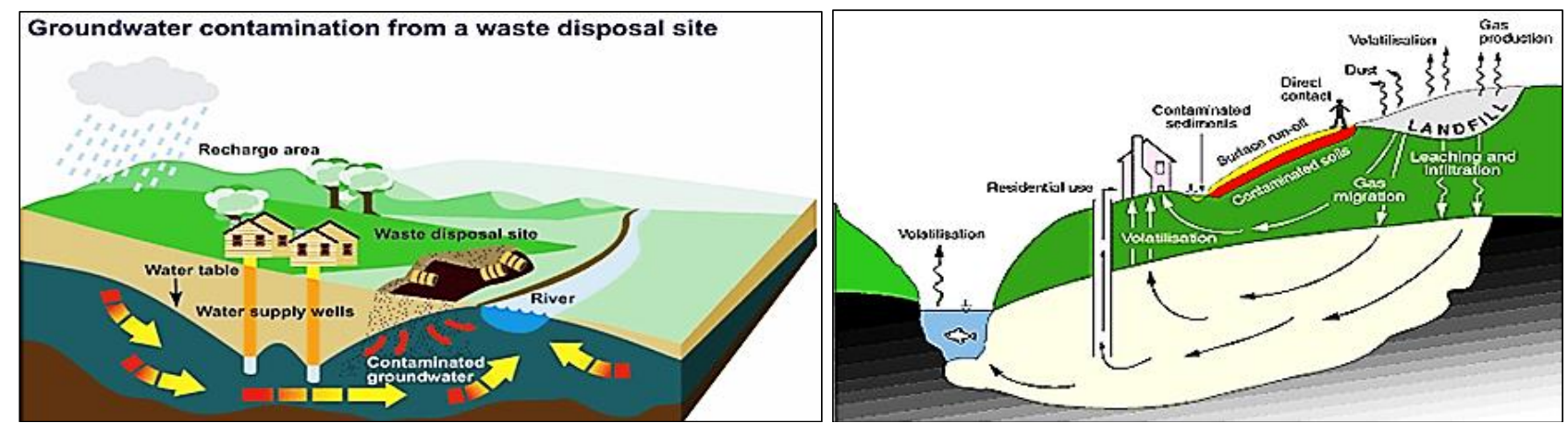

Fig 4: Pollution due to Landfill and Ground Water (Sawe, 2018) ${ }^{[21] .}$

\section{Soil Fertility Effect and Health Impacts}

The organic material decay and toxic substances generate a high impact on the quality of soil around the landfill sites, creating a compound biodiversity effects on vegetation in the surrounding region. Landfill areas impact the natural surroundings and landscape. The place stinks, develop trashy visual appearance becoming a bacteria breeding source. The foul smell, vermin, polluted traffic, noisy situation accompanies landfills, reducing land prices. The vermin around landfills are the major cause to produce diseases, the main issue with many adverse birth defects, health effects, respiratory illnesses, cancer and they all are linked with landfill site exposure (Da Costa, et al., 2018) ${ }^{[7]}$.

\section{Research, Development Summary}

(a) Risk assessment: Presently, there are insufficient sources to perform enough risk management and assessment for the requisite waste management amenities in a convenient manner. Even though the required skills are accessible, the dedicated or personnel resources are presently made available. Further, the there exists sufficient data gaps and these problems should be identified and rectified adequately and urgently.

(b) Human health and Environment impacts, detection and monitoring: The health information and management system fails to sustain and support regular health monitoring of residential society, people staying near the landfills and waste sites. Hence, there is an urgent necessity to generate the resources and skills needed to undertake environmental and health risk assessment in every country. This aspect should be taken on a priority basis, and a crucial progress to build and protect public health associated with probable environmental hazards. Therefore, there are proposals and recommendations for a National Landfill related Environmental and human Health Action Plans to form and substantiate the basis issues of this (Oteng-Ababio, 2014) ${ }^{[18]}$. 


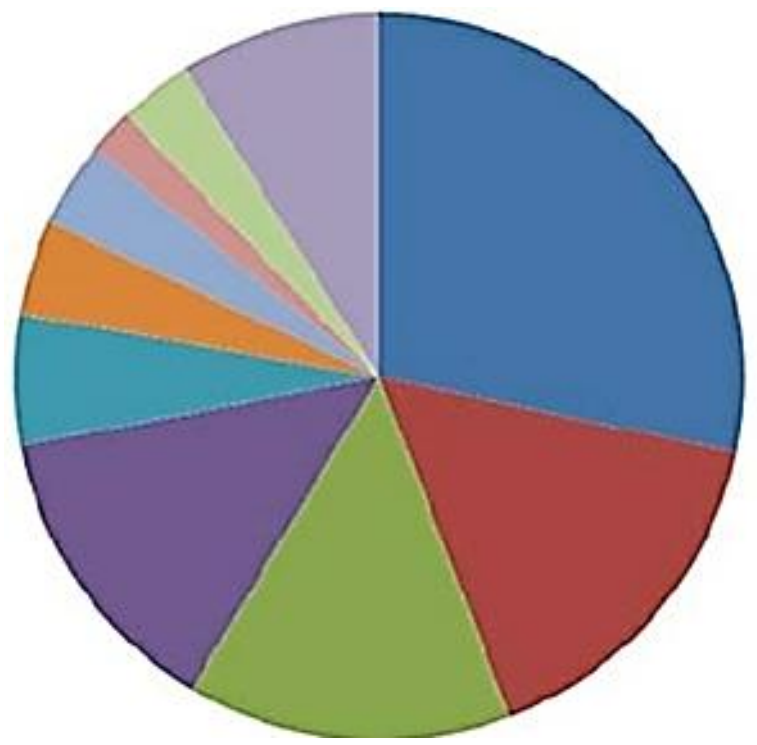

a Mineral cil and gas refineries

a Surfoce treatment of substances, objects or products

a Industrial scale production of basic organic chemicols

a Thermal prower stations and other combustion instalations

a Underground mining and related operations

a Industrial scale production of basic pharmaceutical products

a Production of pulp from timber or similar fibrous materials

- Treatment and processing of animal and vegetable materials in food and drink production a Production of paper and board and other primary wood products a Other

Fig 5: Volatile, Non-methane emission of organic compound from industrial facilities in 2012 (Ojala, et al., 2015) ${ }^{[17]}$.

(c) Monitoring and Detection of environmental impact

The capacity regarding financial facilities, data banks, and human resources should be generated to measure environmental damage due to the landfill, and changes occurred in the course of time the changing situations of the environmental damage due to waste sites, landfills and elsewhere. Also, there are certain critical deficiencies of environmental baseline information in different countries, and those situations must be remedied. Strategically, designed programs and monitoring should be systematically initiated to rectify deficiencies in the prevailing environmental supervision, along with environmental analysis to measure whether dioxins are needed and that should be created on a priority basis. However, this high dioxin public profile should not divert attention and monitoring of other probable pollutants.

(d) Risk communication and perception

The perceptions of waste management qualitative studies revealed a diverse opinion of waste management generated issues, regarding the connection between environmental quality, waste management and human health. The public debate regarding waste management issue of policy and their effects provide a systematic risk communication program to concentrate and obtain trusted and unbiased information from all the participants and stakeholders, regarding the waste management subjects. Public trust will provide the regulated fundamental information in compliance with regulators, to achieve the consensus for the future development programs in waste management and policies (Wasielewska, Banel \& Zygmunt, 2014) ${ }^{[28]}$.

\section{Methods}

The solid waste Methods of management and disposal are Open burning; Sanitary Landfills; Dumping into the sea; Composting; Incineration; Hog feeding; Ploughing in the fields; Discharging into sewers and Grinding; Biological digestion; Fermentation; and Salvaging (Gopal Mishra, 2009) [9].

\section{Methods of Solid Waste Disposal: Sanitary Landfills}

- Waste buried in the ground or carefully piled into mounds

- Designed to prevent groundwater contamination and minimize soil and air pollution
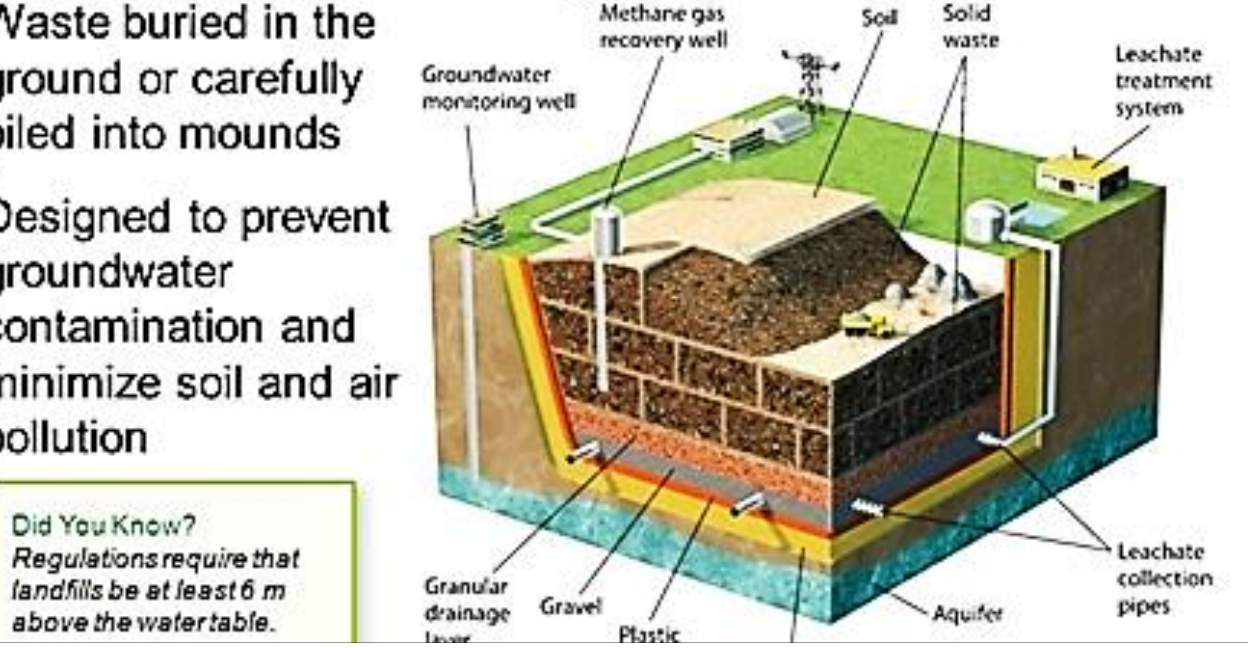

Fig 6: Typical Sanitary Waste Solid Landfill 


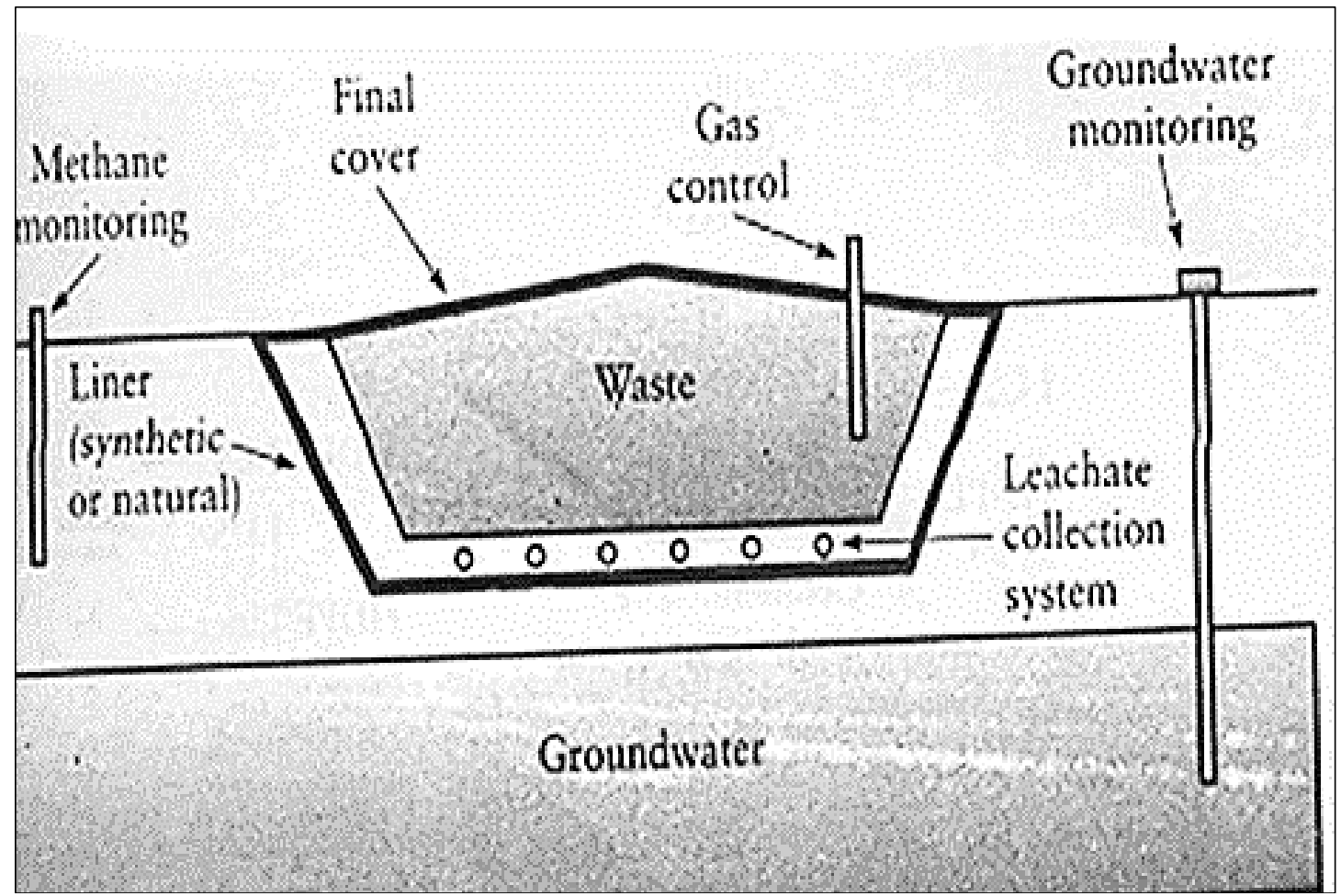

Fig 7: Typical Sanitary Waste Solid Waste (Gopal Mishra, 2009) ${ }^{[9]}$.

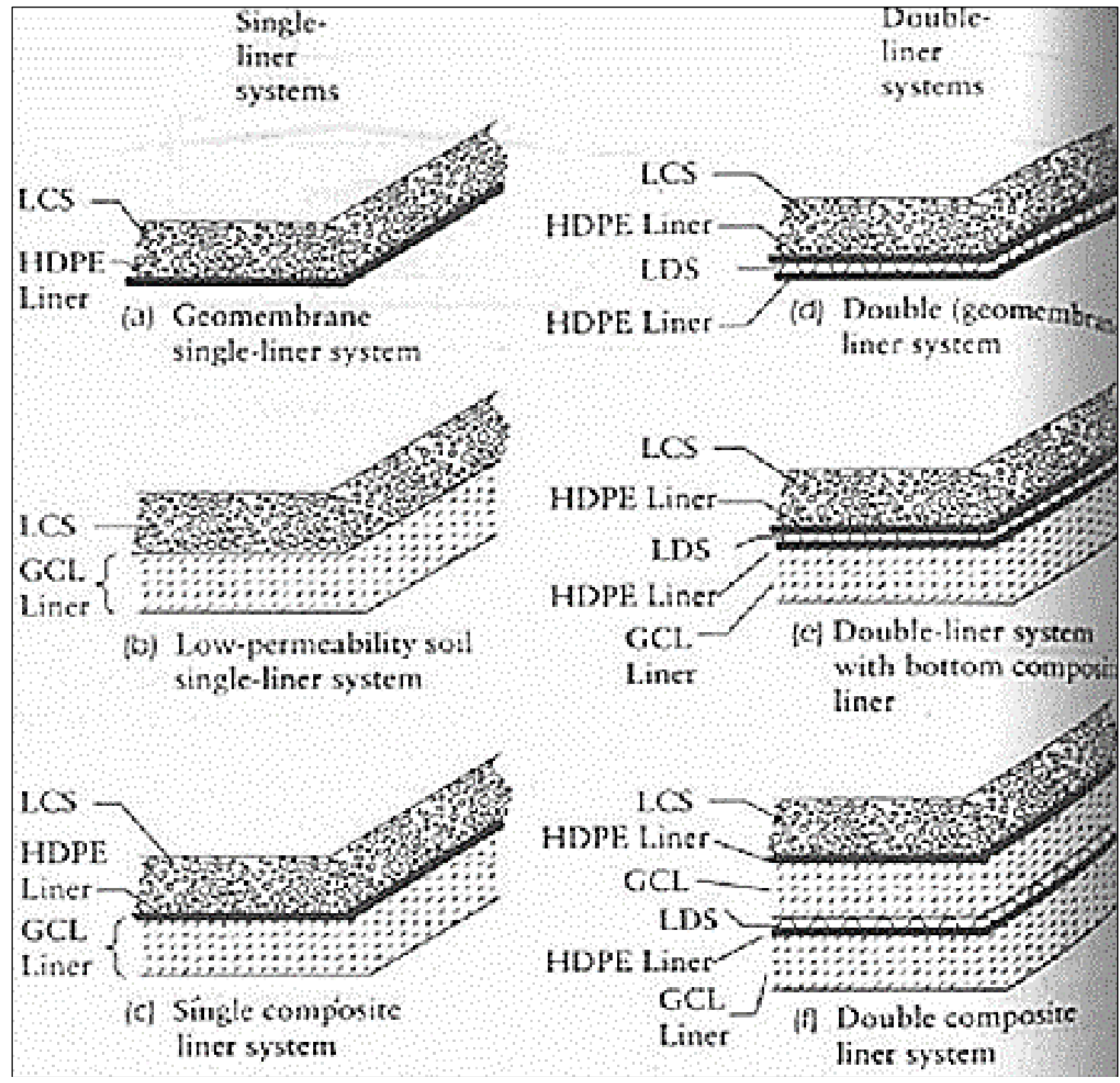

Fig 8 (a): System of municipal solid landfill waste 


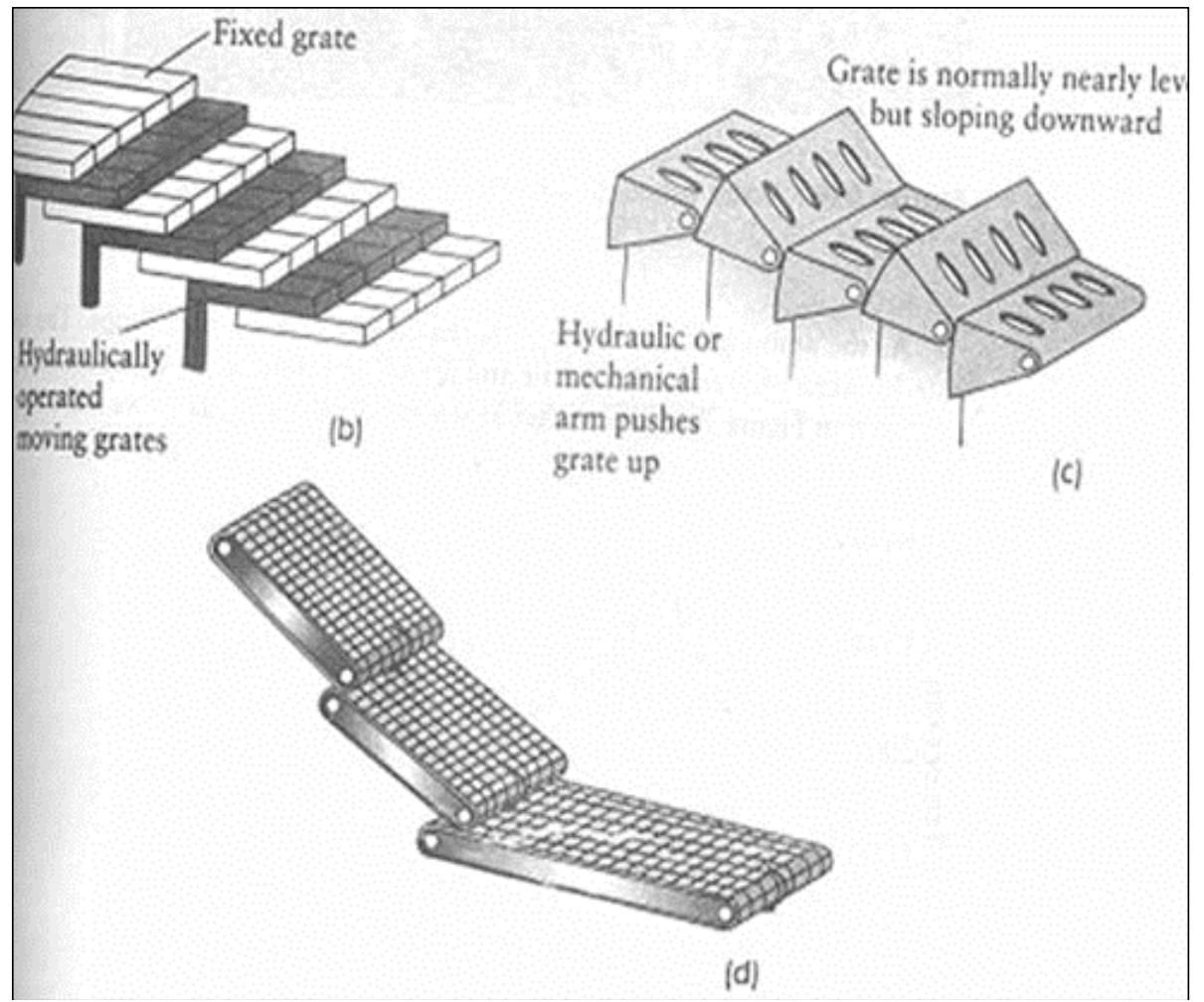

Fig 8 (b): MSW Grates of Combustor

Fire and air are sent through the holes showing three typical grates.

a) Reciprocating Type.

b) Rocking Type.

c) Travelling type (Gopal Mishra, 2009) ${ }^{[9]}$.

Composting Methods are of Open window type and Mechanical type of composting. Aerobic Methods are used with brick pits of $3 \mathrm{~m} \times 3 \mathrm{~m} \times 1 \mathrm{~m}$ dimension, kept the waste materials for 8 to 12 weeks and sent frequently in the pits, thereafter kept on the ground for almost 4 to 6 , and then for 2 weeks done total turnings. Also, in the anaerobic method of earthen trenches are made of dimension $10 \mathrm{~m} \times 1.5 \mathrm{~m} \times 1.5 \mathrm{~m}$ and left for about 5 months for decomposition.
Similarly, Vermicomposting, Salvaging; Hog feeding Disposal; Disposal into fields by Ploughing, Biological Digestion, Fermentation of Waste conversion to compost, Recycling whatever waste is possible

Disposing the Hazardous waste by applying suitable methods, and the rest of them sending to Landfill and incineration (Gopal Mishra, 2009) ${ }^{[9]}$.

A research methodology was carefully examined by researchers, and identified several factors. On the basis of their readings the methodology was developed to create research questions, locating research problems, and preempirical stage theoretical framework formatting, while the data, analyzing, data collection, and interpretation was done in the Empirical stages as shown in below figure.

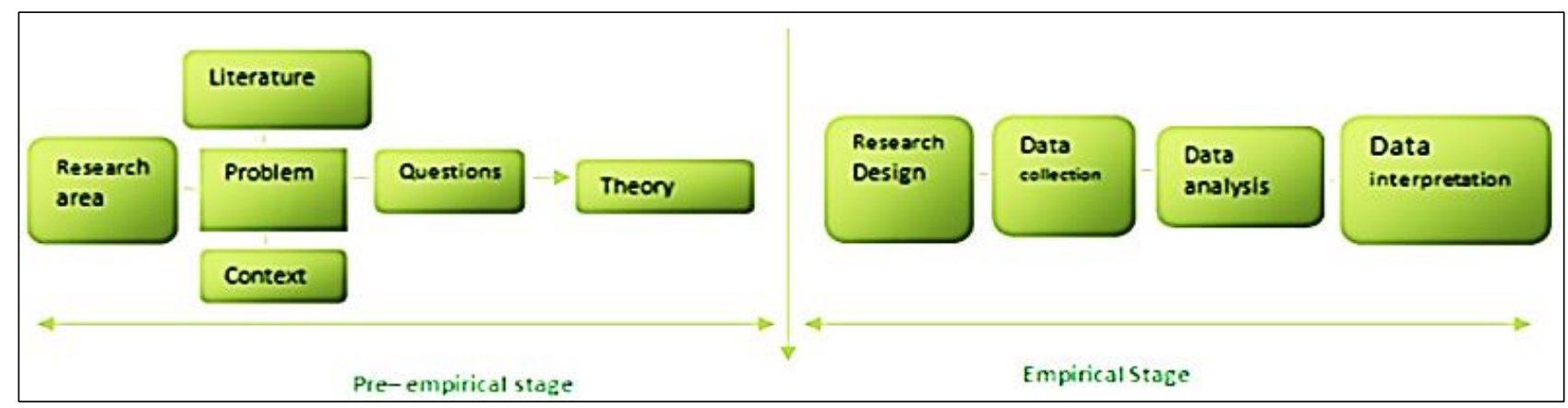

Fig 9: Structure of Pre-empirical and empirical stages

\section{Strategy of Mixed Method}

The methodology, development first stage was to format the strategy of research. As per World Health Organization (WHO, 2001, p.9), the research strategy selection is the core aspect of research method, and also the most crucial research decision to make. Research strategy designs the social research general orientation, conduct of (Bryman, 2012, p.34) [3]. Mainly, researchers rely on qualitative or quantitative strategy of research. Nevertheless, on several instances, the second method of research is included in the study to get a better understanding of the research phase and also improve the primary method (Creswell \& Clark, 2011, p. 10) ${ }^{[6]}$.

The main intention of SWM- Solid Waste Management practice is to understand the impact on environmental and health. Hence, the researcher categorically accepted using the strategy of mixed method, which integrates qualitative and 
quantitative research by analyzing the data, collecting and drawing inferences into one system (Bryman, 2012, p. 628) ${ }^{[3]}$. However, the system of research mainly depends on the qualitative method sequentially abide by quantitative approaches to obtain the overall research process. The mixed method provides a better perception of the study problem (Kumar, 2010:365) ${ }^{[14]}$, particularly, regarding the Questions of Research provides one source of data not sufficient to provide all answers. As per Creswell \& Clark $\left(2011\right.$, p. 8) ${ }^{[6]}$, only the mixed method provides the best opportunity to perform the research with surety to address the problem.

\section{Limitations and Concerns}

1. The Waste Management technology needs soil drying before treatment;

2. Performance Limited Data concerning the hazardous waste containing system treated with PCBPolychlorinated Biphenyls, dioxins related organics. The system that destroys molecules of chlorinated organic by heat carry the ability to develop products that come with incomplete combustion compounds, like Furans and Dioxins, which are extremely toxic, though in tiny amount of trillion ranges. However, this process does not generate Furans and Dioxins.

3. The molten, ash and spent salt are hazardous and need special disposal methods, normally recycled in the reactor compartment.

4. The Pyrolysis process is not helpful in physically separating or destroying organics out of contaminated sources. Volatile metals are not possible to entirely destroy and their by-products should be stabilized prior to final disposal.

5. When the gases generated are cooled, the condensed liquid develops tar and oil residue with contaminated water, which are hazardous wastes, and need proper treatment, and disposal (Kelly \& Fussell, 2015) ${ }^{[12]}$.

\section{Can the Landfill Pollution Effects Be Reversed?}

Environmental pollutants enter water, soil, air, and also spread all over the rivers, oceans and land by natural tendencies and forces due to water flow and wind energy. Certain pollutants degrade the entire environment, which persist for several decades. When the pollution increases and spreads to mix and accumulate in the environment, the cleanup difficulties and cost also increase. In the course of time, the pollution effects on the environment can be contained, slowed and probably reversed by combining various sources to remove pollution and properly clean up (Mavis Kent, 2017) ${ }^{[16]}$.

\section{Pollution Sources}

The major cities are the major part of this cause to contribute towards pollution formation from several sources, including smokestack from factories; car exhaust; contaminated and waste water; landfill liquid leakage and solid disbursement; leakages from sewage pipes and treatment plants; gases released from sewage and landfill; and residential sewage. Pollution from forest lands and rural areas include storm water runoff in crop fertilizers; blowing dust; the smoke from burning fields and forest fires; logging of soil erosion; storm water acid and chemical runoff from mining regions. Also, Pollution entering soil, air, and water can harm by continuously spreading even after the harmful sources are blocked (Cong, Freedman \&Park, 2014) ${ }^{[5]}$.

\section{Environmental Pollution Persistence}

Volatile and Soluble pollutants can degrade in case they are exposed to the atmosphere or the microbes enter the groundwater and soil. Several different kinds of pollutants reposition in the groundwater, subsurface in the form of solution and particles. There are Hydrophobic pollutants, which repel water and liquid particles to be held inside the ground. This is because, they get attracted to sediment particles in the soil, making them costly and complicated to clean with concentrated efforts. They persistently remain in the environment to move towards the food chain through the soil into the food of human consumption, or from other sediment in the sea, towards fish and finally to people (Pevnitskaya \&Ryvkin, 2011) ${ }^{[19]}$.

\section{Pollution Cleaning Up}

Removing pollution using the biggest source can include, for instance, more systematic, overall industrial wastewater treatment or storm water management that includes road pollutants and fertilizers to reduce the pollution amount by entering water streams, river water and the ocean. Several technologies are presently applied to get rid of water and soil pollutants. For instance, the charcoal filtering method is used to remove contaminants; many chemicals are used to neutralize pollutants or bond with related compounds; microorganism process is further used to interrupt and break down compounds of chemicals to neutralize them; and various plants are utilized to break down and extract pollutants. Such advanced technologies can be integrated to make the cleanup procedure more effective (Sihabuddin \&Ariaratnam, 2009) ${ }^{[23]}$.

\section{Curbing Pollution Sources}

The Reversing Process and the effects generated by pollution needs the individuals, societies and government take an additional efforts to reduce water contamination, waste generation to ensure sustainability of better resource. Reuse, Changes, Recycling the product packing system can further reduce the waste generation and avoid them going to landfills. Substitute and Unconventional chemicals can be utilized by several industries and homeowners to remove chemical toxicity involved in wastewater. By applying certain innovative methods and alternative sources of energy can reduce the fossil fuel amount burned and thus reduce the toxicity mount of air emissions (Tribbett, 2012) ${ }^{[24]}$.

\section{References}

1. Adamović VM, Antanasijević DZ, Ćosović AR, Ristić MĐ, Pocajt VV. An artificial neural network approach for the estimation of the primary production of energy from municipal solid waste and its application to the Balkan countries. Waste Manag. 2018; 78:955-968.

2. Alobaid F, Al-Maliki WAK, Lanz T, Haaf M, Brachthäuser A, Epple B, Zorbach I. Dynamic simulation of a municipal solid waste incinerator. Energy. 2018; 149:230-249.

3. Bryman A. Social Research Methods, 4th edition. New York: Oxford University Press, 2012.

4. Chen YCH. Evaluating greenhouse gas emissions and energy recovery from municipal and industrial solid waste using waste-to-energy technology. J Clean. Prod. 2018; 192:262-269.

5. Cong Y, Freedman M, Park J. "Measuring Environmental Performance: Is Newsweek's Green Ranking the Solution?", Accounting for the Environment: More Talk 
and Little Progress (Advances in Environmental Accounting \& Management 5), Emerald Group Publishing Limited. 2014; 5:49-79. https://doi.org/10.1108/S1479-359820140000005011.

6. Creswell JW. Designing and conduction mixed method research. SAGE publication, 2011.

7. Da Costa FM, Daflon SDA, Bila DM, Da Fonseca FV, Campos JC. Evaluation of the biodegradability and toxicity of landfill leachates after the pretreatment using advanced oxidative processes. Waste Manag. 2018; 76:606-613.

8. Ghosh Sadhan Kumar. Waste Valorisation and Recycling: 7th Icon SWM-ISWMAW 2017, Volume 2, Environmental Science, 2019.

9. Gopal Mishra. Methods of Solid Waste Disposal and Management, Environmental Engineering, 2009. https://theconstructor.org/environmental-engg/methodsof-solid-waste-disposal/4721/

10. Hoornweg D, Bhada-Tata P. What a Waste: A Global Review of Solid Waste Management. In: Urban development series, knowledge papers. Washington: World Bank, 2012.

11. Ikiara MM, Karanja AM, Davies TC.. Collection, transportation and disposal of urban solid waste. In: Nairobi in Solid Waste Management and Recycling, Geo Journal Library, 2004, 61-91. https://archpublichealth.biomedcentral.com/track/pdf/10. 1186/s13690-016-0166-4

12. Kelly FJ, Fussell JC. Air pollution and public health: emerging hazards and improved understanding of risk. Environ Geochem Health. 2015; 37:631-649.

13. Kivimägi J. "A descriptive analysis of post-closedown environmental monitoring and maintenance of the Pääsküla landfill", Management of Environmental Quality. 2011; 22(6):769-786. https://doi.org/10.1108/14777831111170867

14. Kumar R. Research Methodology: A Step by Step Guide for Beginners, 3rd Ed. London: Sage Publications Ltd, 2010.

15. Kumar Gupta S, Gupta S, Gayathiri S. "Pollution prevention" is the key to drive sustainability: Preliminary findings from a tannery unit in India", Management of Environmental Quality. 2018; 29(3):416-426. https://doi.org/10.1108/MEQ-10-2017-0124.

16. Mavis Kent. Can the Effects of Pollution Be Reversed?, Science, Nature, Environment, 2017. https://sciencing.com/can-effects-pollution-reversed23523.html

17. Ojala S, Koivikko N, Laitinen T, Mouammine A, Seelam PK et al. Utilization of Volatile Organic Compounds as an Alternative for Destructive Abatement. Catalysts. 2015; 5:1092-1151.

18. Oteng-Ababio M. "“Guilty with explanation": rethinking the destiny of landfills in a Millennium City in Ghana", Management of Environmental Quality. 2014; 25(2):200215. https://doi.org/10.1108/MEQ-11-2012-0074

19. Pevnitskaya S, Ryvkin D. "Behavior in a Dynamic Environment with Costs of Climate Change and Heterogeneous Technologies: An Experiment", Isaac, R. and Norton, D. (Ed.) Experiments on Energy, the Environment, and Sustainability (Research in Experimental Economics), Emerald Group Publishing Limited, Bingley. 2011; 14:115-150. https://doi.org/10.1108/S0193-2306(2011)0000014007.
20. Rada EC, Ragazzi M, Stefani P, Schiavon M, Torretta V. Modelling the Potential Biogas Productivity Range from a MSW Landfill for Its Sustainable Exploitation. Sustainability. 2015; 7:482-495.

21. Sawe, Benjamin Elisha. "What Are The Major Sources Of Groundwater Contamination?" World Atlas, Aug. 28, 2018, worldatlas.com/articles/what-are-the-majorsources-of-groundwater-contamination.html.

22. Shen S, Chen Y, Zhan L, Xie H, Bouazza A, He F, Zuo $X$. Methane hot spot localization and visualization at a large-scale Xi'an landfill in China: Effective tool for landfill gas management. J Environ. Management. 2018; 225:232-241.

23. Sihabuddin S, Ariaratnam S. "Methodology for estimating emissions in underground utility construction operations", Journal of Engineering, Design and Technology. 2009; 7(1):37-64. https://doi.org/10.1108/17260530910947259.

24. Tribbett K. "Chapter 6 Win, Lose, or Draw? Assessing the Success of the Environmental Justice Movement in Emissions Trading Schemes", Holt, W. (Ed.) Urban Areas and Global Climate Change (Research in Urban Sociology), Emerald Group Publishing Limited, Bingley. 2012; 12:135-167. https://doi.org/10.1108/S10470042(2012)0000012009.

25. UNEP. Cal Recovery Inc. Solid Waste Management. Tsurumi-ku: UNEP International Environmental Technology Centre (IETC) and California: Cal Recovery, Inc., California, USA, 2005. https://archpublichealth.biomedcentral.com/track/pdf/10. 1186/s13690-016-0166-4

26. Vaverková Magdalena Daria. Landfill Impacts on the Environment-Review, Geosciences. 2019; 9(10):431. https://doi.org/10.3390/geosciences9100431.

27. Wang B, Shen Y. The Performance of an anaerobic baffled reactor (ABR) as a hydrolysis-acido-genesis unit in treating landfill leachate mixed with municipal sewage. Water Sci. Technol. 2000; 42:115-121.

28. Wasielewska M, Banel A, Zygmunt B. Emission and Determination of Malodorous Compounds from Municipal Solid Waste Sites and Wastewater Treatment Plants. Int Conf Environ Sci Technol. 2014; 69:99-103.

29. WHO. Health research methodology: a guide for training in research methods, 2001.

30. Zhao C, Zhang Y, Xie D. The Multi-energy High precision Data Processor Based on AD7606. IOP Conf. Service. Earth Environ. Science. 2017; 94:0121-38.

31. Ziyang L, Luochun W, Nanwen Y, Youcai Z. Martial recycling from renewable landfill and associated risks: A review. Chemosphere. 2015; 131:91-103.

32. Ziraba et al. A review and framework for understanding the potential impact of poor solid waste management of health in developing countries, Archives of Public Health. 2016; 74:55. DOI 10.1186/s13690-016-0166-4. 